\title{
Primary tuberculosis of the parotid gland: a forgotten diagnosis about a case!
}

\author{
ELMOSTAFA BENAISSA ${ }^{1}$, MOHAMED HABIB BAHALOU ${ }^{1}$, YASSINE SAFI ${ }^{1}$, FATNA \\ BSAIBISS $^{1}$, YASSINE BENLAHLOU ${ }^{1}$, MARIAMA CHADLI ${ }^{1}$, ADIL MALEB ${ }^{1}$, and \\ MOSTAFA ELOUENNASS ${ }^{1}$
}

${ }^{1}$ Affiliation not available

November 27, 2020

\begin{abstract}
Primary tuberculosis of the parotid gland is rare even in endemic countries. the clinical manifestations are polymorphic and non-specific. it is important for clinicians to be aware of this pathology.
\end{abstract}

\section{Hosted file}

Figure 1.pdf available at https://authorea.com/users/379290/articles/495523-primarytuberculosis-of-the-parotid-gland-a-forgotten-diagnosis-about-a-case

\section{Hosted file}

Figure 2.pdf available at https://authorea.com/users/379290/articles/495523-primarytuberculosis-of-the-parotid-gland-a-forgotten-diagnosis-about-a-case 